\title{
ANALYSES OF POTABLE SPIRITS USED BY THE NATIVE POPULATION IN INDIA.
}

\section{By Harold H. Mann.}

There are very few analyses of distilled liquor, as prepared by native methods in India, on record, or at any rate accessible. This is the more remarkable as the extremely serious physiological effect of these spirits has long been noticed, and has been currently attributed to the addition, by the retailers of the liquor, of various noxious drugs, especially hemp (ganja). It has seemed, therefore, of importance to obtain analyses of a series of samples of liquor, as sold by the retail dealers of India, in order not only to ascertain whether the current opinion as to the presence of alkaloidal poisons derived from such drugs was well founded, but also to obtain information as to what is their composition with regard to the more usual constituents of distilled liquor.

In the following preliminary series of analyses of spirits, which were all obtained in Bengal and Assam, only the more ordinary constituents have been determined. The higher alcohols have been estimated by the German official method, revised by Röse. As this method has been recently severely criticised by Schidrowitz, ${ }^{*}$ I hope to repeat the determinations on a fresh series of samples, by the method which he prefers, on my return to India. Every sample has been tested for alkaloids (which have, however, been uniformly found to be absent) and many for furfurol (by means of the colour reaction with anilin), and this is found to be a constant by-product. I hope shortly to go carefully into the question of the quantity of both furfurol and aldehydes, to which great importance is attached, from a physiological point of view, by recent workers. 1

The samples I have obtained may be divided into four classes:

1. Those derived from mahua-that is, from the flowers of Bassia latifolia.

2. Those obtained from rice.

3. Those from the refuse of sugar manufacture.

4. Those representing imported foreign low-grade spirit, imported, it seems, chiefly from Germany.

1. This comprises mahua spirit, by far the most important class in Bengal and in Assam the first. The mahua flowers used for the purpose are exceedingly rich in sugar, and may, as bought, contain as much as 58 per cent. of fermentable sugars (on the dry matter present). The fermentation and distillation are extremely crude, and the former is carried out in such strong solution that complete fermentation rarely takes place. The amount of total sugar in the liquor ready for fermentation may, in fact, reach 20 per cent. The yeast used is transferred from one batch of liquor to the next for a long time, and as the fermentation is never very vigorous, one would expect to find, as actually appears to be the case, a very large proportion of higher alcohols.

The analyses of my samples gave figures as follows. I give first the actual

* Jinurual of the Society of Chemical Industry, June 30, 1902.

$\dagger$ Hewitt, Journal of the Society of Chcmical Industry, January, 1902; Lauder Brunton and Tumnicliffe, Lancet, December 8, 1900, and June 2, 1902. 
percentage composition (except for the alcohol, which is reported as degrees under proof), and then the number of grains per gallon of proof spirit, in order to reduce the figures to a common alcohol basis.

Table I.-Percentage Composivion.

\begin{tabular}{|c|c|c|c|c|c|c|c|}
\hline No. & $\begin{array}{l}\text { Source and Cost } \\
\text { of Spirit. }\end{array}$ & Alcohol. & $\begin{array}{l}\text { Fixed Acids } \\
\text { (as Tartaric). }\end{array}$ & $\begin{array}{l}\text { Volatile Acids } \\
\text { (as Acetic). }\end{array}$ & $\begin{array}{c}\text { Solid } \\
\text { Residue. }\end{array}$ & Ash. & $\begin{array}{l}\text { Higher } \\
\text { Alcohols. }\end{array}$ \\
\hline & & $\begin{array}{l}\text { Degrees } \\
\text { under } \\
\text { Proof. }\end{array}$ & Per Cent. & Per Cent. & Per Cent. & $\begin{array}{l}\text { Per } \\
\text { Cent. }\end{array}$ & Per Cent. \\
\hline 1 & Calcutta, 1 pint, & $22 \cdot 2$ & 0.069 & 0.074 & 0.026 & 0.004 & $0 \cdot 332$ \\
\hline 2 & 9 annas $\ldots$ & $32 \cdot 1$ & 0.021 & 0.052 & 0.023 & 0.003 & $0 \cdot 302$ \\
\hline 4 & $\begin{array}{l}\text { Calcutta, } \frac{1}{2} \text { pint, } \\
8 \text { annas } \\
\text { Calcutta, } \frac{1}{2} \text { pint, }\end{array}$ & 4 & No & $\mathrm{No}$ & $0 \cdot 242$ & 0.010 & 0.040 \\
\hline 5 & $\begin{array}{l}8 \text { annas } \\
\text { Calcutta, } \frac{1}{2} \text { pint }\end{array}$ & $57 \cdot 8$ & 0.027 & 0.031 & $0 \cdot 126$ & 0.008 & 0.043 \\
\hline & 8 annas $\ldots$ & $39 \cdot 5$ & 0 . & & $0 \cdot$ & 0.002 & $0 \cdot 196$ \\
\hline 6 & Assam ... & $64 \cdot 9$ & 0. & & 0. & 0.002 & $0 \cdot 106$ \\
\hline 7 &,$\quad \ldots$ & $63 \cdot 2$ & 0.033 & $0 \cdot 103$ & $0 \cdot 010$ & 0.001 & $0 \cdot 239$ \\
\hline
\end{tabular}

Table II.-Composition in Grains per Proof Gallon.

\begin{tabular}{|c|c|c|c|c|c|c|}
\hline No. & Source. & $\begin{array}{c}\text { Fixed Acids } \\
\text { (as Tartaric Acid). }\end{array}$ & $\begin{array}{l}\text { Volatile Acids } \\
\text { (as Acetic Acid). }\end{array}$ & $\begin{array}{c}\text { Solid } \\
\text { Residue. }\end{array}$ & Ash. & $\begin{array}{l}\text { Higher } \\
\text { Alcohols. }\end{array}$ \\
\hline $\begin{array}{l}1 \\
2 \\
3 \\
4 \\
5 \\
6 \\
7\end{array}$ & $\begin{array}{c}\text { Calcutta } \\
\text {," } \\
, \\
, \\
\text { Assam } \\
\text {," }\end{array}$ & $\begin{array}{c}62 \cdot 1 \\
21 \cdot 7 \\
\text { None. } \\
44 \cdot 1 \\
72 \cdot 6 \\
70 \cdot 0 \\
62 \cdot 8\end{array}$ & $\begin{array}{r}66 \cdot 6 \\
53 \cdot 6 \\
\text { None. } \\
50 \cdot 7 \\
87 \cdot 1 \\
191 \cdot 5 \\
195 \cdot 9\end{array}$ & $\begin{array}{r}23 \cdot 4 \\
23 \cdot 7 \\
327 \cdot 7 \\
206 \cdot 0 \\
51 \cdot 8 \\
33 \cdot 9 \\
19 \cdot 0\end{array}$ & $\begin{array}{r}3 \cdot 6 \\
3 \cdot 3 \\
13 \cdot 5 \\
13 \cdot 1 \\
3 \cdot 5 \\
4 \cdot 0 \\
1 \cdot 9\end{array}$ & $\begin{array}{r}298 \cdot 5 \\
311 \cdot 0 \\
54 \cdot 3 \\
72 \cdot 1 \\
226 \cdot 6 \\
211 \cdot 0 \\
623 \cdot 1\end{array}$ \\
\hline
\end{tabular}

The two samples from Assam are not made from mahua flowers alone, but a variable proportion of crude locally-made sugar (ghur) is mixed into the liquid obtained. In Bengal it is usual to use only mahua flowers.

2. Rice Spirit.-Only one sample of spirit made from rice has come into my hands; it was purchased under the name Doasta in Calcutta, and gave the following figures :

Table III.-Percentage Composition.

\begin{tabular}{c|c|c|c|c|c|c|c} 
No. & Source. & Alcohol. & Fixed Acids. & $\begin{array}{c}\text { Volatile } \\
\text { Acids. }\end{array}$ & Solid Residue. & Ash. & $\begin{array}{c}\text { Higher } \\
\text { Alcohols. }\end{array}$ \\
\hline & & $\begin{array}{c}\text { Degrees } \\
\text { under Proof. }\end{array}$ & Per Cent. & Per Cent. & Per Cent. & Per Cent. & Per Cent. \\
& Calcutta & 20.8 & 0037 & 0.084 & 0.017 & 0.003 & 0.561 \\
\hline
\end{tabular}

* One anna equals one halfpenny nearly. 
Table IV.-Composition in Grains per Proof Gallon.

\begin{tabular}{c|c|c|c|c|c|c}
\hline No. & Source. & Fixed Acids. & Volatile Acids. & Solid Residue. & Ash. & Higher Alcohols. \\
\hline 8 & Calcutta & 32.7 & $74 \cdot 2$ & 15.0 & 2.5 & 491.8 \\
\hline
\end{tabular}

3. Spirits from Sugar Refuse. -These were two in number, and were in bottles labelled "Shajehønpur Rum."

Table V.-Percentage Composition.

\begin{tabular}{r|cc|c|c|c|c|c}
\hline No. & Sulce. & Alcohol. & Fixed Acids. & $\begin{array}{c}\text { Volatile } \\
\text { Acids. }\end{array}$ & Solid Residue. & Ash. & $\begin{array}{c}\text { Higher } \\
\text { Alcolols. }\end{array}$ \\
\hline & $\begin{array}{c}\text { Degrees } \\
\text { under Proof. } \\
9\end{array}$ & Per Cent. & Per Cent. & Per Cent. & Per Cent. & Per Cent. \\
10 & Calcutta & 530 & Traces. & None. & 0.529 & 0.010 & 0.152 \\
0.006 & $n 6.3$ & 0.008 & 0.163 \\
\hline
\end{tabular}

Table VI.-Composition in Grains per Proof Gallon.

\begin{tabular}{|c|c|c|c|c|c|c|}
\hline No. & Source. & Fised Acids. & Volatile Acids. & Solid Residue. & Ash. & Higher Alcohols. \\
\hline $\begin{array}{r}9 \\
10\end{array}$ & $\begin{array}{c}\text { Calcutta } \\
",\end{array}$ & $\begin{array}{c}\text { Traces. } \\
9 \cdot 6\end{array}$ & $\begin{array}{c}\text { None. } \\
\text { ", }\end{array}$ & $\begin{array}{l}788 \cdot 0 \\
370 \cdot 0\end{array}$ & $\begin{array}{l}15 \cdot 0 \\
12 \cdot 2\end{array}$ & $\begin{array}{l}226 \cdot 5 \\
261 \cdot 6\end{array}$ \\
\hline
\end{tabular}

4. Imported Low Grade Spirits.-These are characterized by the presence of an enormous quantity of organic solid matter (sugar) and a high percentage of higher alcohols. The figures are as follows: No. 11 was marked "Deer Brand Brandy," and No. 12 as "Thistle, Scotch Whisky."

Table VII.-Percentage Composition.

\begin{tabular}{|c|c|c|c|c|c|c|c|}
\hline No. & Source. & Alcohol. & Fixed Acids. & $\begin{array}{l}\text { Volatile } \\
\text { Acids. }\end{array}$ & $\begin{array}{c}\text { Solid } \\
\text { Residue. }\end{array}$ & Ash. & $\begin{array}{l}\text { Higher } \\
\text { Alcohols. }\end{array}$ \\
\hline $\begin{array}{l}11 \\
12\end{array}$ & $\begin{array}{c}\text { Calcutta } \\
,\end{array}$ & $\begin{array}{c}\text { Degrees } \\
\text { under Proof. } \\
58 \cdot 7 \\
58 \cdot 0\end{array}$ & $\begin{array}{c}\text { Per Cent. } \\
\text { None. } \\
,\end{array}$ & $\begin{array}{c}\text { Per Cent. } \\
\text { None. } \\
,\end{array}$ & $\begin{array}{c}\text { Per Cent. } \\
1 \cdot 52 \\
1 \cdot 17\end{array}$ & $\begin{array}{c}\text { Per Cent. } \\
0.02 \\
0.01\end{array}$ & $\begin{array}{c}\text { Per Cent. } \\
0 \cdot 217 \\
0 \cdot 244\end{array}$ \\
\hline
\end{tabular}

Tajle VIII.-Composition in Grains per Proof Gallon.

\begin{tabular}{|c|c|c|c|c|c|c|}
\hline No. & Source. & Fixed Acids. & Volatile Acids. & Solid Residue. & Ash. & Higher Alcohols. \\
\hline $\begin{array}{l}11 \\
12\end{array}$ & $\begin{array}{c}\text { Calcutta } \\
, "\end{array}$ & $\begin{array}{c}\text { None. } \\
\text { ", }\end{array}$ & $\begin{array}{c}\text { None. } \\
\quad "\end{array}$ & $\begin{array}{l}2576 \cdot 3 \\
1950 \cdot 0\end{array}$ & $\begin{array}{l}34 \cdot 9 \\
16 \cdot 7\end{array}$ & $\begin{array}{l}367 \cdot 5 \\
407 \cdot 4\end{array}$ \\
\hline
\end{tabular}

The chief points brought out by the figures thus set out are :

1. The extreme dilution at which the spirit is sold. Only two samples slightly 
exceed 25 degrees under proof, while the bulk of the liquor is sold more than 50 degrees under proof.

2. The large proportion of volatile acids in the spirits prepared by native methods from mahua or rice. This is, of course, the natural result of the extreme impurity of the yeast used, and of the high concentration at which the liquors are usually fermented.

3. The large proportion of fixed acids, for which I have not yet been able to give an explanation.

4. The enormous percentage reached by the higher alcohols (fusel oil). Though the great physiological effect of these higher alcohols is now denied, yet it can hardly be that the enormous proportions indicated by many of my figures can be without injurious influence.

5 . The total absence of alkaloids in all cases.

6. The presence of furfurol in every spirit in which it was tested for, except one of the samples of "Shajehanpur rum."

I hope to return to the subject, with further data concerning a larger number of samples, as well as other constituents such as the aldehydes and furfurol, which have been recently shown to be of considerable physiological importance.

The actual analytical figures were obtained for me by Dr. C. Schulten, to whom I beg to tender my best thanks for his interest in the investigation. 